\title{
PENGUNGKAPAN CORPORATE SOCIAL RESPONSIBILITY (CSR) BANK UMUM SYARIAH BERDASARKAN ISLAMIC SOCIAL REPORTING INDEX (INDEKS ISR)
}

\author{
Apip Zanariyatim, Ai Nur Bayinah dan Oni Sahroni \\ Program Studi Akuntansi Syariah \\ Sekolah Tinggi Ekonomi Islam SEBI \\ Email: apipzanariyatim@gmail.com
}

\begin{abstract}
The purpose of this study was to measure the extent to which the rate of ISR index scores when using the item more comprehensive. The population in this study was 12 BUS (Islamic Banks) and sample selection using purposive sampling BUS which has published the Annual Report 2012 to 2014 on the official website of each. The results obtained from this study is the ISR index score each year experienced a significant improvement in which the acquisition of ISR Index score is the highest in the year 2012-2014 BSM with a score of $89.6 \%$ and the lowest score achieved by BVS of 45.8\%. The predicate obtained BUS until 2014 there were two BUS predicate Very Informative namely: BMI and BSM. Informative predicate achieved by BRIS, BSB, and BNIS. Then four BUS predicate Less Informative are: BMS, BCAS, BJBS, and BPS. While the two BUS more predicate Not Informative is BMS and BVS.
\end{abstract}

Keywords: Corporate Social Responsibility Disclosure, Islamic Banking, Islamic Social Reporting Index.

\section{PENDAHULUAN}

Perkembangan Corporate Social Responsibility (Selanjutnya disebut CSR) di Indonesia saat ini cukup menggembirakan yang mana telah mengalami peningkatan baik dalam kuantitas maupun kualitas dibandingkan dari tahuntahun sebelumnya. Hal ini dapat terlihat dari semakin maraknya unit-unit bisnis yang melaporkan praktik CSR dalam laporan keuangan tahunan maupun press leresa lainnya (Fitria dan Hartanti, 2010). Walaupun pada awalnya pelaporan mengenai CSR bersifat sukarela (Voluntary) menjadi bersifat wajib (Mandatory) (Fauziah dan Yudho, 2013) setelah munculnya undang-undang nomor 40 tahun 2007, yang mewajibkan perseroan bergerak dalam bidang sumber daya alam atau bidang lainnya yang terkait untuk melaporkan pelaksanaan tanggung jawab sosial pada laporan tahunan (Putra, 2014).

Dapat diasumsikan bahwa pelaporan mengenai CSR menjadi perhatian khusus bagi perusahaan dalam memproduksi suatu barang ataupun jasa agar tidak mengganggu kenyamanan disekitarnya. Sehingga hal ini bukan hanya kepatuhan pada undang-undang semata melainkan suatu kewajiban yang mesti diterapkan oleh perusahaan.

Perusahaan yang mampu mengungkapkan CSR dengan baik, akan memberikan feedback yang positif bagi perusahaan. Dalam memperoleh 
suatu kepercayaan dari berbagai pihak mengenai usaha yang dijalankan, beberapa perusahaan berlomba-lomba untuk memberikan value yang terbaik bagi para pihak internal maupun ekternal dengan memberikan informasi bahwa setiap perilaku serta tindakannya tidak merusak makhluk disekitarnya. Sebab pada hakikatnya ketika suatu perusahaan telah mendapatkan value yang lebih dari berbagai pihak bukan tidak mungkin perusahaan tersebut telah menjadi lebih maju dari sebelumnya sehingga pada akhirnya dapat memperbaiki performa keuangan, menaikkan citra merek, serta menambah daya tarik terhadap perusahaan sebagai tempat kerja yang baik (Gustani dan Bayinah, 2014). Adapun dalam pernyataan Fitria dan Hartanti (2010), bahwa praktik dalam pengungkapan CSR telah banyak dilakukan oleh perusahaan go public di Indonesia yang pada umumnya bergerak dalam bidang pertambangan atau manufaktur, dikarenakan perusahaan tersebut memiliki resiko pencemaran lingkungan yang lebih tinggi ketimbang perusahaanperusahaan yang lainnya. Namun hingga pada akhirnya praktik CSR diikuti oleh sektor perbankan.

Dalam penelitian Sofyani dan Setiawan, (2012) menemukan bahwa dalam konsep CSR juga terdapat dalam ajaran Islam yang mana ketika menjalankan suatu bisnisnya harus berdasarkan prinsip syariah dan mendasarkan pada filosofi dasar Al Qur'an dan As-Sunnah, sehingga menjadikan dasar bagi pelakunya dalam berinteraksi dengan lingkungan dan sesamanya. Dengan pernyataan tersebut dapat dicermati bahwa lembaga syariah lebih cenderung memperhatikan lingkungannya dengan baik dikarenakan tanggung jawab lembaga syariah bukan hanya kepada stakeholder melainkan memiliki tanggung jawab langsung kepada Allah SWT. Selain itu, lembaga syariah memiliki hubungan yang kuat antara lembaga tersebut dengan lingkungannya dibandingkan dengan lembaga non syariah. Lebih lanjut Sofyani dan Setiawan, (2012) menjelaskan bahwasanya kesempurnaan iman seorang muslim tidak dapat hanya dicapai dengan hubungan vertikal kepada Allah saja (Hablumminallah)-kesalehan Individual, tetapi juga harus dibarengi dengan hubungan yang baik kepada sesama makhluk ciptaan Allah (Hablumminannas)-kesalehan sosial.

Salah satu lembaga yang operasionalnya sesuai dengan prinsip-prinsip syariah serta berlandaskan pada Al-Qur'an dan As-Sunnah adalah Bank Syariah. Sebagaimana tujuan utama dari pendirian Bank Syariah itu sendiri sebagai upaya kaum muslimin untuk mendasari segenap aspek kehidupan ekonominya, (Antonio, 2001). Sejatinya fungsi dari perbankan syariah adalah sebagai intermediary antara pihak yang memiliki kelebihan dana kepada pihak yang kekurangan dana hal ini guna mewujudkan suatu kesejahteraan.

Perkembangan perbankan syariah di Indonesia juga cukup menggembirakan dengan melihat banyaknya kantor bank syariah, maupun penghimpunan dan pembiayaan dibandingkan dengan sejak berdirinya Bank Syariah pertama di Indonesia. Adapun berdasarkan data yang diperoleh dari Otoritas Jasa Keuangan (OJK) dalam Statistik Perbankan Syariah (SPS) sampai bulan Desember 2014, Bank Umum Syariah (BUS) di Indonesia berjumlah 12, Unit Usaha Syariah (UUS) berjumlah 22. Sedangkan total aset 
BUS dan UUS per Desember 2014 telah mencapai Rp272,34 triliun dengan jumlah DPK sebesar Rp217,86 triliun dan pembiayaan yang diberikan sebesar Rp199,33 triliun.

Dalam hal ini yang menjadi tantangan bagi bank syariah saat ini adalah mewujudkan kepercayaan dari para stakeholder. Kepercayaan dari stakeholder tersebut mampu memberikan dampak positif bagi perkembangan bank itu sendiri. Sebagaimana harapan dari para pemegang saham terhadap bank syariah tidak sama dengan bank konvensional yang hanya memiliki tujuan profit semata. Ruang lingkup bank syariah atau lembaga keuangan syariah lebih luas dari pada Bank Konvensional yang mana dalam menjalankan kegiatan usahanya, lembaga keuangan syariah selalu sejalan dengan prinsip-prinsip syariah termasuk didalamnya mengatur segala aspek perilaku serta tindakan yang diperbuat oleh lembaga, sehingga pada akhirnya dapat mewujudkan kesejahteraan bagi orang lain (Sofyani dan Setiawan, 2012).

Pelaporan sosial berdasarkan nilai-nilai islami atau sering disebut dengan Islamic Social Reporting (Selanjutnya disebut ISR) merupakan salah satu upaya bank syariah dalam memberikan informasi mengenai kinerja sosial bank syariah kepada stakeholder sekaligus menjawab atas pengukuran CSR disclosure yang berkembang saat ini yang masih mengacu pada Global Reporting Initiative Index (indeks GRI) (Fitria dan Hartanti, 2010). Sedangkan menurut Haniffa (2002), hal ini justru tidak logis bagi bank syariah yang memiliki nilai-nilai syariah dalam melaporkan kinerja sosialnya memakai alat ukur yang sama dengan bank konvensional. Karena pada dasarnya jenis informasi yang perlu disajikan berbeda antara perspektif islam dengan perspektif konvensional. Adapun lebih lajut dalam penelitian Haniffa (2002), mengusulkan prinsip-prinsip etika dan isi dari ISR berdasarkan lima dimensi: keuangan dan investasi, produk, sumber daya insani, masyarakat dan lingkungan. Secara khusus indeks ISR adalah perluasan dari social reporting yang meliputi harapan masyarakat tidak hanya mengenai peran perusahaan dalam perekonomian, tetapi juga peran perusahaan dalam perspektif spiritual.

Beberapa penelitian terkait indeks ISR perbankan telah banyak dilakukan oleh para peneliti diantaranya Haniffa (2002), Othman dan Thani (2010), Othman et al (2009). Sedangkan di Indonesia sendiri telah dikembangkan oleh berbagai peneliti seperti Fitria dan Hartanti (2010), Sofyani dan Setiawan (2012), Sofyani et al (2012), Fauziah dan Yudho (2013), Gustani dan Bayinah (2013), Putra (2014) dan beberapa penelitian yang lain baik dalam bentuk jurnal maupun skripsi.

Adapun menurut Haniffa (2002) "ISR adalah upaya pelaporan aspekaspek sosial dalam aktivitas lembaga keuangan syariah dalam perspektif Islam sebagai sebuah alternatif untuk mereduksi kelemahan dalam praktik di lembaga keuangan syariah." Oleh karena itu, hadirnya ISR kepada lembaga keuangan syariah dapat membawa dampak yang positif serta memberikan efek manfaat bagi pihak-pihak yang membutuhkan informasi sosial guna memenuhi pertanggung jawaban atas segala perilaku dan tindakan yang 
dilakukan, sebab yang menjadi tanggung jawab bagi lembaga keuangan syariah bukan hanya kepada pemilik modal melainkan memiliki ruang lingkup yang lebih luas sehingga bisa mendapatkan keridhaan Allah SWT.

Mengingat begitu pentingnya implementasi indeks ISR dalam pelaporan CSR di bank syariah, memicu para peneliti untuk menguji dan menganalisis penerapan indeks ISR itu sendiri pada bank syariah di Indonesia. Seperti penelitian yang dilakukan oleh Fitria dan Hartanti (2010), yang membandingkan pengungkapan berdasarkan Global Reporting Initiative Index dengan Islamic Social Reporting Index. Hasil penelitian ini menyimpulkan bahwa tingkat pengungkapan tanggung jawab sosial pada tiga bank syariah masih terbatas atau hanya dapat memenuhi $50 \%$ jika diukur dengan Islamic Social Reporting Index, pengungkapan berdasarkan Global Reporting Initiative Index lebih tinggi skore nya daripada Islamic Social Reporting Index. Dikarenakan indikator Islamic Social Reporting Index kurang komprehensif.

Penelitian Fauziah dan Yudho (2013), dengan melakukan analisis terhadap pengungkapan tanggung jawab sosial perbankan syariah di Indonesia berdasarkan Islamic Social Reporting. Penelitian ini mengambil objek perbankan syariah sebanyak 7 Bank Umum Syariah di Indonesia dengan menggunakan annual report tahun 2011. Hasil yang didapatkan yakni skor indeks ISR tertinggi adalah Bank Muamalat Indonesia yaitu sebesar $73 \%$ dan skor terendah adalah bank panin syariah dengan skor $41 \%$.

Adapun penelitian yang dilakukan Gustani dan Bayinah (2013), dalam jurnalnya yang berjudul model pelaporan kinerja sosial perbankan syariah: implementasi Islamic Social Reporting (indeks ISR) di Indonesia. Dalam penelitian ini mengambil sampel 5 bank umum syariah yakni: Bank Muamalat Indonesia (BMI), Bank Syariah Mandiri (BSM), Bank Mega Syariah Indonesia (BMSI), Bank Rakyat Indonesia Syariah (BRIS), dan Bank Syariah Bukopin (BSB) dengan pengambilan annual report 2009-2011. Hasil yang diperoleh bahwa tingkat pengungkapan kinerja sosial tertinggi periode 2009-2011 adalah BSM. Secara keseluruhan, tingkat pengungkapan kinerja sosial BUS di Indonesia dalam periode 2009-2011 terus mengalami peningkatan setiap tahunnya.

Penelitian lain dilakukan oleh Putra (2014) yang juga meneliti mengenai pelaksanaan dan pengungkapan Corporate Social Responsibility pada perbankan syariah di Indonesia berdasarkan indeks Islamic Social Reporting (ISR). Penelitian ini fokus pada bank syariah yang menjadi pemenang penghargaan Corporate Image Award 2012 yaitu Bank Syariah Mandiri, Bank Muamalat Indonesia, Bank Negara Indonesia Syariah, dan Bank Mega Syariah Indonesia. Hasil yang diperoleh bahwa rata-rata pengungkapan semua bank syariah yang menjadi sampel adalah 57\%. Dari keempat sampel yang diteliti hanya 3 sampel yang mampu mencapai angka lebih dari 50\%. Dimana yang memperoleh angka tertinggi adalah Bank Syariah Mandiri.

Dari penelitian-penelitian sebelumnya dapat dilihat bahwa pengungkapan Corporate Social Responsibility pada bank syariah di 
Indonesia berdasarkan Indeks Islamic Social Reporting (ISR) masih belum maksimal. Sebagaimana dengan penelitian yang dilakukan oleh Fitria dan Hartanti (2010) mendapatkan hasil yang kurang maksimal, dikarenakan penerapan ISR di Bank Syariah Indonesia masih terlalu asing untuk diterapkan. Sedangkan pada tahun 2013 telah mengalami perkembangan yang sangat bagus dimana dalam penelitian Fauziah dan Yudho (2013) menunjukkan bahwa bank syariah di Indonesia dalam hal pengungkapan Corporate Social Responsibility berdasarkan Indeks Islamic Social Reporting (ISR) sudah cukup optimal. Begitupun dengan penelitian yang dilakukan oleh Gustani dan Bayinah (2013) yang memperoleh hasil bahwa setiap tahunnya tingkat kinerja sosial bank syariah selalu meningkat. Namun secara keseluruhan rata-rata tingkat pengungkapan kinerja sosial BUS di Indonesia masih kurang informatif. Dilanjutkan dengan hasil temuan Putra (2014) terhadap bank syariah di Indonesia yang memperoleh penghargaan Corporate Image Award 2012. Pada bank syariah tersebut pengungkapan Corporate Social Responsibility berdasarkan Indeks Islamic Social Reporting (ISR) sudah baik dengan menunjukkan hasil diatas $50 \%$ pada ketiga sampel bank syariah yang diteliti.

Secara umum hasil dari penelitian Fauziah dan Yudho (2013) berbeda dengan hasil penelitian yang dilakukan Gustani dan Bayinah (2013), dan penelitian Putra (2014). Namun hasil penelitian yang dilakukan oleh Gustani dan Bayinah (2013) sama dengan hasil penelitian Putra (2014). Dalam hal ini, hasil yang diperoleh dari penelitian Fauziah dan Yudho (2013), menunjukkan bahwa bank syariah di indonesia yang menduduki tingkat tertinggi dalam pengungkapan CSR berdasarkan ISR adalah Bank Muamalat Indonesia (BMI). Sedangkan hasil penelitian Gustani dan Bayinah (2013) sama dan penelitian Putra (2014), menunjukkan bahwa bank syariah di Indonesia yang memiliki tingkat tertinggi dalam pengungkapan CSR berdasarkan ISR diduduki oleh Bank Syariah Mandiri (BSM).

Dapat diasumsikan bahwa perbedaan hasil dari penelitian Fauziah dan Yudho (2013), penelitian Gustani dan Bayinah (2013), dan penelitian Putra (2014) dikarenakan menggunakan sampel, periode dan indikator ISR yang berbeda. Hal ini yang kemudian menjadi suatu pertanyaan apakah suatu Bank Syariah setiap tahunnya mengalami kemuduran dalam pelaporan CSR berdasarkan ISR, sehingga dapat diungguli oleh Bank Syariah lainnya. Atau bisa jadi performa suatu Bank Syariah dalam pelaporan CSR berdasarkan ISR stabil, namun Bank Syariah lainnya menunjukkan kinerja yang lebih baik tiap tahunnya sehingga bisa mendapatkan peringkat pertama dalam pelaporan CSR berdasarkan ISR

\section{LANDASAN TEORI}

\subsection{PENGUNGKAPAN CSR}

Pengungkapan CSR menurut Sulaiman dan Willet (2003) dalam Suhendi dan Indriastuti (2014), adalah informasi wajib yang harus diungkapkan dalam 
laporan tahunan perusahaan atau disajikan secara terpisah dalam laporan keberlanjutan. Sedangkan Muttakin dan Khan (2014) dalam Ullah dan Rahman (2013) mengemukakan pengungkapan CSR sebagai "CSR disclosure has positive and significant relationships with export-oriented sector, firm size and types of industries and a negative relationship between CSR disclosure and family ownership". Definisi tersebut menjelaskan bahwa dalam mengungkapkan CSR perusahaan memiliki hubungan yang positif dan signifikan dengan berorientasi pada nilai ekspor, ukuran perusahaan dan jenis industry. Sedangkan hubungan yang bersifat negatif yaitu antara pengungkapan CSR dan kepemilikan keluarga.

Utomo (2000) dalam Cahyati (2008) menyatakan bahwa tema-tema yang diungkapkan dalam wacana akuntansi tanggung jawab sosial adalah:

1. Kemasyarakatan, mencakup aktivitas kemasyarakatan yang diikuti perusahaan, misalnya aktivitas terkait dengan kesehatan, pendidikan, dan seni, serta pengungkapan aktivitas kemasyarakatan lainnya.

2. Ketenagakerjaan, meliputi dampak aktivitas perusahaan pada orangorang dalam perusahaan tersebut. Aktivitas tersebut meliputi rekruitment, program pelatihan, gaji dan tunjangan, mutasi dan promosi, dan lainnya (Othman et al, 2009).

3. Produk dan konsumen, melibatkan aspek kualitatif suatu produk atau jasa, antara lain kegunaan, durability, pelayanan, kepuasan pelanggan, kejujuran dalam iklan, kejelasan atau kelengkapan isi pada kemasan.

4. Lingkungan hidup, yaitu aspek lingkungan dari proses produksi, yang meliputi pengendalian polusi dalam menjalankan operasi bisnis, pencegahan dan perbaikan kerusakan lingkungan akibat pemprosesan sumber daya alam dan konversi sumber daya alam.

\subsection{ISLAMIC SOCIAL REPORTING (ISR)}

Munculnya ISR (Islamic Social Reporting) pertama kali digagas oleh Haniffa (2002) dalam tulisannya yang berjudul "Social Reporting Disclosure: An Islamic Perspective”. Menurut Haniffa (2002) terdapat banyak keterbatasan dalam laporan sosial yang dipakai Bank Konvensional, sehingga ia mengemukakan kerangka konseptual ISR berdasarkan ketentuan syariah yang mana bentuk pelaporan ini akan dipakai oleh lembaga syariah karena menurut beliau tidak etis bagi entitas bisnis yang bergerak dibidang syariah dan melakukan aktivitas sesuai prinsip syariah tapi masih mengacu pada pedoman Bank Konvensional. Pada dasarnya ISR ini tidak hanya membantu dalam pengambilan keputusan bagi pihak muslim, melainkan dapat membantu perusahaan dalam pertanggung jawabannya kepada Allah SWT, masyarakat, lingkungan, spiritual, hak minoritas, dan karyawan (Fitria dan Hartanti, 2010). 
ISR ini dikembangkan lebih lanjut oleh Othman et al (2009) dalam tulisannya yang berjudul "Determinant Of Islamic Social Reporting Among Top Sharia-Approved Companies in Bursa Malaysia" dan masih banyak lagi penelitian mengenai ISR yang dikembangkan oleh berbagai peneliti selanjutnya termasuk di Indonesia sendiri.

\subsection{ISLAMIC SOCIAL REPORTING INDEX (INDEKS ISR)}

Indeks ISR merupakan suatu standar pelaporan atas pengungkapan CSR perusahaan-perusahaan yang berbasis syariah. Indeks ini berisi kompilasi item-item pengungkapan CSR yang ditetapkan oleh AAOIFI (Accounting and Auditing Organization for Islamic Financial Institutions) yang kemudian dikembangkan oleh para peneliti selanjutnya sehingga item-item tersebut dianggap relavan untuk digunakan oleh entitas syariah.

Adapun, beberapa peneliti yang telah mengembangkan Indeks ISR diantaranya: Haniffa (2002) yang menggagas Indeks ISR yang kemudian dilanjutkan oleh Othman et al (2009). Adapun Haniffa (2002) membuat lima tema pengungkapan Indeks ISR, yaitu Tema Pendanaan dan Investasi, Tema Produk dan Jasa, Tema Karyawa, Tema Masyarakat, dan Tema Lingkungan Hidup. Kemudian dikembangkan oleh Othman et al (2009) dengan menambahkan satu tema pengungkapan yaitu tema Tata Kelola Perusahaan.

\subsection{PENELITIAN TERDAHULU}

Penelitian mengenai Indeks ISR pertama kali diteliti oleh Haniffa (2002) dengan judul "Social Reporting Disclosure: An Islamic Perspective". Hasil yang diperoleh bahwa praktik pengungkapan sosial secara syariah harus berbeda dengan pelaporan sosial yang dipakai oleh konvensional karena pada dasarnya prinsip yang dipakai oleh keduanya berbeda. Prinsip yang dipakai dalam islam selalu mengedepankan prinsip-prinsip syariah sedangkan dalam bingkai konvensional hanya mempertimbangkan nilai material saja. Selanjutnya Haniffa dan Hudaib (2007) kembali meneliti dengan judul "Exploring the Ethical Identity of Islamic Banks via Communication in Annual Reports" yang bertujuan apakah terdapat perbedaan antara informasi yang diungkapkan berdasarkan annual report dengan berdasarkan etika bisnis islam. Hasil yang diperoleh bahwa keseluruhan rata-rata Indeks Identitas Etis terdapat satu Bank Syariah yang mendapatkan nilai diatas ratarata dari tujuh Bank Syariah yang diteliti. Sedangkan enam Bank Syariah lagi menderita disparitas antara yang dikomunikasikan dan identitas etis ideal.

Peneliti dari Malaysia Othman et al (2009) melakukan penelitian dengan tujuan untuk mengidentifikasi faktor-faktor yang dapat mempengaruhi perusahaan dalam menyediakan ISR sebagai bentuk pelaporan sosialnya. Hasil yang diperoleh bahwa dari empat faktor yang teliti hanya terdapat tiga faktor yang berpengaruh secara signifikan terhadap perusahaan diantaranya: ukuran, profitabilitas, dan komposisi dewan. Sedangkan satu faktor yang tidak berpengaruh adalah jenis industry. Selanjutnya Othman dan Thani (2010) melakukan penelitian dengan tujuan mengukur sejauh mana ISR yang telah dilakukan oleh perusahaan syariah 
yang terdaftar di Bursa Malaysia dalam Annual Report. Adapun hasil yang diperoleh bahwa tingkat ISR dalam Annual Report yang dipilih dianggap masih minim.

Adapun berbagai peneliti di Indonesia yang juga meneliti tentang ISR diantarnya: Fitria dan Hartanti (2010) yang membandingkan bank syariah dengan Bank Konvensional dengan alat ukut ISR dan GRI. Hasil yang diperoleh bahwa Bank Syariah memperoleh skor tertinggi dengan alat ukur Indeks GRI dibandingkan dengan alat ukur Indeks ISR. Kemudian Fauziah dan Yudho (2013) melakukan studi komparatif antar setiap Bank Syariah di Indonesia berdasarkan Islamic Social Reporting. Hasil yang diperoleh bahwa skor Indeks ISR tertinggi diraih oleh Bank Muamalat dengan skor sebesar $73 \%$ dan skor terendah adalah Bank Panin Syariah dengan skor $41 \%$.

Sofyani dan Setiawan (2012) meneliti tentang tanggung jawab sosial Bank Syariah dengan mengkomparasikan Bank Syariah di Indonesia dengan di Malaysia dengan menggunakan alat ukur ISR dan GRI. Hasil yang diperoleh bahwa kinerja sosial Bank Syariah di Malaysia lebih tinggi dibandingkan dengan Bank Syariah di Indonesia. Namun ketika di uji secara statistik terdapat Bank non Syariah di Indonesia dan Malaysia yang mendapatkan nilai $100 \%$ antara kinerja sosial ISR dan GRI. Kemudian Sofyani et al (2012) kembali meneliti tentang perbandingan kinerja sosial pada tiga Bank Syariah di Indonesia dengan Bank Syariah di Malaysia. Hasil yang diperoleh hampir sama yaitu kinerja sosial Bank Syariah di Malaysia lebih tinggi dari Bank Syariah di Indonesia, namun Bank Syariah di Indonesia terdapat peningkatan yang signifikan pada tahun 2010 sebesar $10 \%$ sedangkan di Malaysia stabil. Secara keseluruhan tidak ada satu pun Bank Syariah di Indonesia maupun di Malaysia yang memperoleh skor $100 \%$.

Putra (2014) meneliti tentang pelaksanaan dan pengungkapan CSR Bank Syariah yang mendapatkan penghargaan dibidang lingkungan hidup dengan menggunakan ISR. Hasil yang diperoleh adalah rata-rata pengungkapan semua perusahaan pada tahun 2012 dan 2013 adalah sebesar $57 \%$ dengan kenaikan prosentase total pengungkapan sebesar 2,2\% dari tahun ke tahun. Kemudian pada penelitian Saridona dan Cahyandito (2015) yang bertujuan untuk mengeksplorasi kinerja sosial Bank Syariah dengan menggunakan ISR, dimana hasil yang peroleh secara umum kinerja Bank Syariah yang terungkap pada laporan tahunan 2013 mendapatkan predikat "BAIK" dengan skor 61,73\%. Sedangkan dari keseluruhan Bank Syariah yang diteliti yang memperoleh peringkat tertinggi adalah BSM dan peringkat terendah diperoleh BVS.

Gustani dan Bayinah (2014) dalam jurnalnya yang berjudul "Model pelaporan kinerja sosial perbankan syariah : implementasi islamic social reporting index (Index ISR) di Indonesia" dengan sampel yang diteliti sebanyak lima BUS tahun 2009-2011. Hasil yang diperoleh bahwa tingkat pengungkapan tertinggi adalah BSM dan secara keseluruhan predikat yang diperoleh seluruh BUS adalah kurang informatif. Sedangkan Azizah dan Birton (2015) meneliti pengungkapan CSR Bank Syariah berdasarkan buku 1 dan buku 2 dengan alat ukur ISR, namun pada penelitian ini hanya 
menggunakan tiga tema dari enam tema. Hasil yang diperoleh bahwa pengungkapan Indeks ISR setiap tahunnya mengalami peningkatan yang signifikan. Semakin lama Bank Syariah berdiri maka semakin tingg tingkat pengungkapan ISR begitupun sebaliknya Bank Syariah yang baru berdiri relatif tidak mengungkapkan tanggung jawab sosial secara spesifik.

Berdasarkan hasil penelitian terdahulu mengenai tangung jawab sosial Bank Syariah dan Indeks ISR, peneliti tertarik untuk meneliti kembali tingkat pengungkapan CSR Bank Syariah berdarkan ISR. Adapun, kesamaan penelitian ini dengan penelitian-penelitian terdahulu adalah terletak pada objek penelitian, penggunaan alat ukur Indeks ISR, dan analisis data yang digunakan adalah analisis isi (content analysis). Sedangakan perbedaannya terletak pada jumlah item yang diteliti, periode penelitian, dan tujuan utama dari penelitian.

\section{METODE PENELITIAN}

Metode penelitian yang digunakan pada penelitian ini adalah metode kualitatif yang bertujuan untuk mengetahui tingkat pengungkapan CSR pada Bank Syariah di Indonesia berdasarkan Indeks ISR melalui laporan tahunan (Annual Report) Bank Umum Syariah (BUS).

Variabel dalam penelitian yang dilakukan adalah dengan menggunakan pengungkapan CSR berdasarkan ISR, yang mana komponen tersebut mengacu pada Hannifa (2002), Haniffa dan Hudaib (2007), Othman et al (2009), Fauziah dan Yudho (2013), Gustani dan Bayinah (2014) serta penelitian-penelitian sebelumnya

Analisis data dalam penelitian ini dilakukan dengan cara content analysis. Menurut Bungin (2006), metode analisis isi merupakan suatu teknik sistematik untuk menganalisis isi pesan dan mengolah pesan atau suatu alat untuk mengobservasi dan menganalisis perilaku komunikasi yang terbuka dari komunikator yang dipilih. Adapun langkah-langkah untuk menunjang analisis isi tersebut adalah sebagai berikut:

1. Langkah pertama yaitu mengidentifikasi dan mengklasifikasikan berbagai informasi yang terdapat dalam laporan tahunan Bank Umum Syariah di indonesia sesuai dengan item-item ISR yang digunakan.

2. Melakukan penilaian (scoring) indeks ISR pada Bank Umum Syariah. Scoring dilakukan untuk mencari poin pengungkapan yang dinilai dengan 1 jika terdapat sub-tema yang diungkapkan dan 0 jika terdapat sub-tema yang tidak diungkapkan dari item pengungkapan yang telah dijabarkan dalam tabel.

3. Selanjutnya akan dilakukan analisis konten terhadap tiap-tiap tema indeks ISR pada setiap Bank Umum Syariah untuk mengetahui tingkat pengungkapan CSR Bank Syariah. Selanjutnya dilakukan penilaian secara kumulatif indeks ISR pada Bank Umum Syariah (BUS) yang akan menentukan tingkat pengungkapan CSR Bank Umum Syariah (BUS). 
4. Untuk memudahkan dalam mengetahui seberapa besar tingkat pengungkapan CSR di Bank Umum Syariah maka dilakukan rumus sebagai berikut:

Indek ISR $=$ Jumlah Poin yang diungkapkan X 100\%

Jumlah Skor Maksimal

5. Setelah melakukan penilaian (scoring) atas item-item indeks ISR, maka selanjutnya menentukan predikat tingkat pengungkapan CSR dari masing-masing BUS. Dalam penilaian tingkat pengungkapan kinerja sosial BUS, akan digunakan pendekatan yang mengacu pada Munawaroh (2007) dalam Gustani (2013) dimana skor pengungkapan diklasifikasikan dalam 4 kategori: Sangat Informatif (81-100), Informatif (66-80), Kurang informatif (51-66) dan tidak informatif (0-50).

Tabel 1. Predikat tingkat pengungkapan CSR Bank Syariah Berdasarkan Indeks ISR

\begin{tabular}{cc}
\hline Predikat & Nilai Indeks \\
\hline Sangat Informatif & $81 \%-100 \%$ \\
\hline Informatif & $66 \%-80 \%$ \\
\hline Kurang Informatif & $51 \%-65 \%$ \\
\hline Tidak Informatif & $0 \%-50 \%$ \\
\hline
\end{tabular}

Sumber: Munawaroh (2007) dalam Gustani dan Bayinah (2014

Secara keseluruhan, pada tahun 2012 Bank Umum Syariah yang mendapatkan predikat Sangat Informatif diraih oleh Bank Muamalat, dan Bank Syariah Mandiri. Hal ini dirasa wajar karena Bank Syariah tersebut telah berdiri lebih dulu dibandingkan dengan Bank Syariah yang lainnya. Selain itu, Bank Muamalat pada lima tahun terakhir ini mendapatkan 100 penghargaan yang bergensi, salah satunya pada tahun 2012 mendapatkan penghargaan bergengsi sebagai "Best Islamic Bank in Indonesia" dan "The Most Innovative Islamic Bank" dari Islamic Finance News. Hal ini menunjukkan bahwa dari waktu ke waktu, Bank Muamalat berupaya untuk mendorong pertumbuhan bisnis yang lebih agresif dengan disertai oleh peningkatan kualitas layanan dan terus melakukan inovasi agar dapat menjadi leader di industri perbankan syariah. Sedangkan Bank Syariah Mandiri pada tahun 2014 mendapatkan penghargaan sebagai "Corporate Image Award" dari majalah tempo media group bekerja sama dengan frontier consulting group.

Tabel 2. Tingkat Predikat Pengungkapan Bank Umum Syariah Pada Tahun 2012-2014

No Nama Tahun




\begin{tabular}{lllll}
\hline & BUS & \multicolumn{1}{c}{2012} & \multicolumn{1}{c}{2013} & \multicolumn{1}{c}{2014} \\
\hline 1 & BMI & Sangat Informatif & Sangat Informatif & Sangat Informatif \\
\hline 2 & BSM & Sangat Informatif & Sangat Informatif & Sangat Informatif \\
\hline 3 & BMS & Kurang Informatif & Kurang Informatif & Kurang Informatif \\
\hline 4 & BRIS & Informatif & Informatif & Informatif \\
\hline 5 & BSB & Informatif & Kurang Informatif & Informatif \\
\hline 6 & BNIS & Kurang Informatif & Informatif & Informatif \\
\hline 7 & BVS & Tidak Informatif & Tidak Informatif & Kurang Informatif \\
\hline 8 & BCAS & Kurang Informatif & Kurang Informatif & Kurang Informatif \\
\hline 9 & BJBS & Kurang Informatif & Kurang Informatif & Kurang Informatif \\
\hline 10 & BPS & Tidak Informatif & Kurang Informatif & Informatif \\
\hline 11 & MBS & Tidak Informatif & Tidak Informatif & Tidak Informatif \\
\hline & & Sumber: Diolah dari data Sekunder &
\end{tabular}

Predikat Informatif secara konsisten diraih oleh Bank Rakyat Indonesia, sedangkan Bank Negara Indonesia memperoleh predikat Informatif ditahun 2013 dan 2014 yang mana sebelumnya hanya mendapatkan predikat Kurang Informatif padahal pada tahun 2012 Bank Syariah tersebut memperoleh penghargaan dibidang Good Corporate Governance dan laba yang diperoleh juga meningkat 53,6\%. Kemudian Bank Panin Syariah pada tahun 2014 memperoleh predikat Informatif padahal tahun sebelumnya hanya mendapatkan predikat Tidak Informatif dan Kurang Informatif hal ini diasumsikan bahwa kegiatan sosial yang dilakukan oleh Bank Syariah tersebut pada tahun 2014 sangat bagus yag mana terdapat pemberian beasiswa pendidikan kepada mahasiswa STID Al Hikmah Mampang, pembeian dana pendidikan untuk yayasan Al-Kahfi, pengadaan Al-Qur'an terjemahan bagi karyawn dll.

Predikat Kurang Informatif dan Tidak Infomatif selalu didominasi oleh Bank Mega Syariah, Bank Victoria Syariah, Bank Centra Asia Syariah, Bank Jabar Banten Syariah dan Maybank Syariah. Adapun untuk melihat seberapa banyak Bank Syariah dan prosentasenya dalam memperoleh predikat secara kumulatif pada tahun 2012 sampai 2014 dapat disajikan berdasarkan grafik:

Grafik 1. Tingkat Prosentase Predikat Pengungkapan Indeks ISR Kumulatif Bank Umum Syariah Pada Tahun 2012-2014 


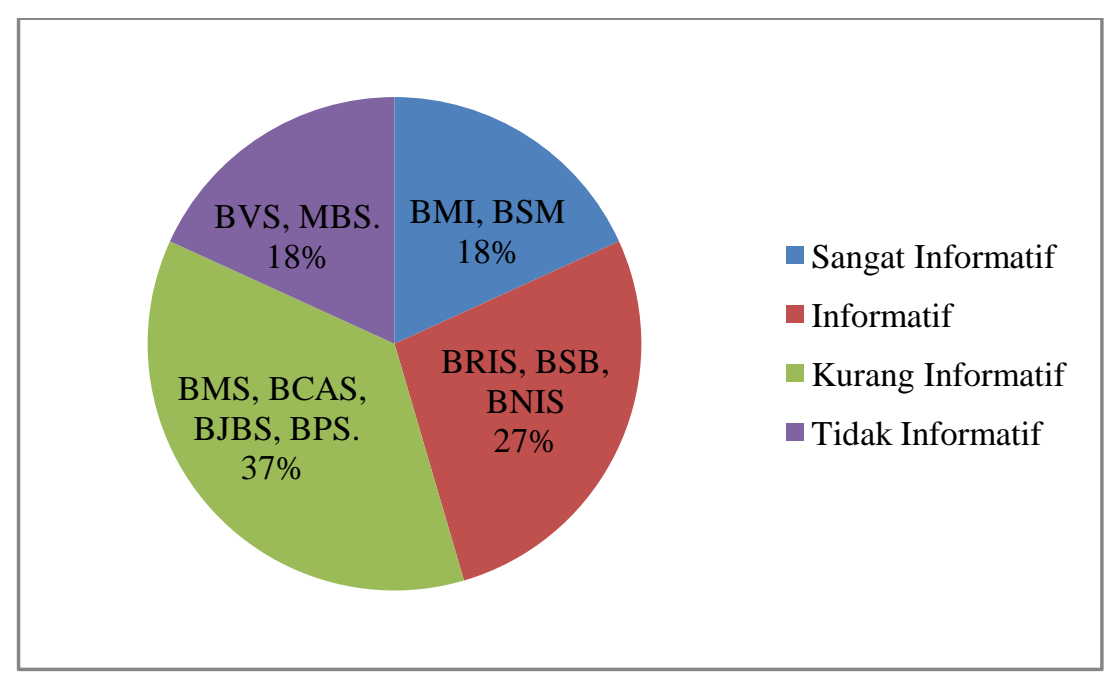

Sumber: Diolah dari data sekunder.

Dari Grafik diatas dapat disimpulkan bahwa selama tahun 2012 sampai 2014, Bank Umum Syariah lebih banyak mendapatkan predikat kurang informatif yang mana skor yang diperoleh sebesar 37\%. Sedangkan Bank Syariah yang memperoleh predikat sangat informatif secara konsisten diraih oleh Bank Muamalat dan Bank Syariah Mandiri, skor tersebut sama dengan hasil yang diperoleh Bank Victoria Syariah dan Maybank Syariah yang secara konsisten berada pada predikat Tidak Informatif. Sedangkan predikat Informatif selama tiga tahun terakhir diraih oleh Bank Rakyat Indonesia Syariah, Bank Syariah Bukopin, dan Bank Negara Indonesia Syariah. Adapun dapat disajikan kembali perolehan skor dan nilai secara kumulatif, sebagaimana dalam tabel berikut.

Tabel 3. Tingkat pengungkapan Indeks ISR Bank Umum Syariah pada tahun 2012-2014

\begin{tabular}{llllllll}
\hline \multirow{2}{*}{ No } & \multirow{2}{*}{ Nama BUS } & \multicolumn{2}{c}{2012} & \multicolumn{2}{c}{2013} & \multicolumn{2}{c}{2014} \\
\cline { 3 - 8 } & & Nilai & Skor & Nilai & Skor & Nilai & Skor \\
\hline 1 & BMI & 69 & $86,3 \%$ & 69 & $86,3 \%$ & 67 & $83,8 \%$ \\
\hline 2 & BSM & 73 & $91,3 \%$ & 76 & $95 \%$ & 66 & $82,5 \%$ \\
\hline 3 & BMS & 44 & $55 \%$ & 48 & $60 \%$ & 46 & $57,5 \%$ \\
\hline 4 & BRIS & 56 & $70 \%$ & 61 & $76,3 \%$ & 61 & $76,3 \%$ \\
\hline 5 & BSB & 59 & $73,8 \%$ & 52 & $65 \%$ & 54 & $67,5 \%$ \\
\hline 6 & BNIS & 51 & $63,8 \%$ & 61 & $76,3 \%$ & 61 & $76,3 \%$ \\
\hline 7 & BVS & 30 & $37,5 \%$ & 39 & $48,8 \%$ & 41 & $51,3 \%$ \\
\hline
\end{tabular}




\begin{tabular}{llllllll}
\hline 8 & BCAS & 43 & $53,8 \%$ & 46 & $57,5 \%$ & 43 & $53,8 \%$ \\
\hline 9 & BJBS & 45 & $56,3 \%$ & 42 & $52,5 \%$ & 46 & $57,5 \%$ \\
\hline 10 & BPS & 38 & $47,5 \%$ & 50 & $62,5 \%$ & 57 & $71,3 \%$ \\
\hline 11 & MBS & 37 & $46,3 \%$ & 40 & $50 \%$ & 36 & $45 \%$ \\
\hline
\end{tabular}

Sumber: Diolah dari data sekunder

Grafik 2. Perbandingan Indeks ISR pada Bank Umum Syariah Pada Tahun 2012-2014

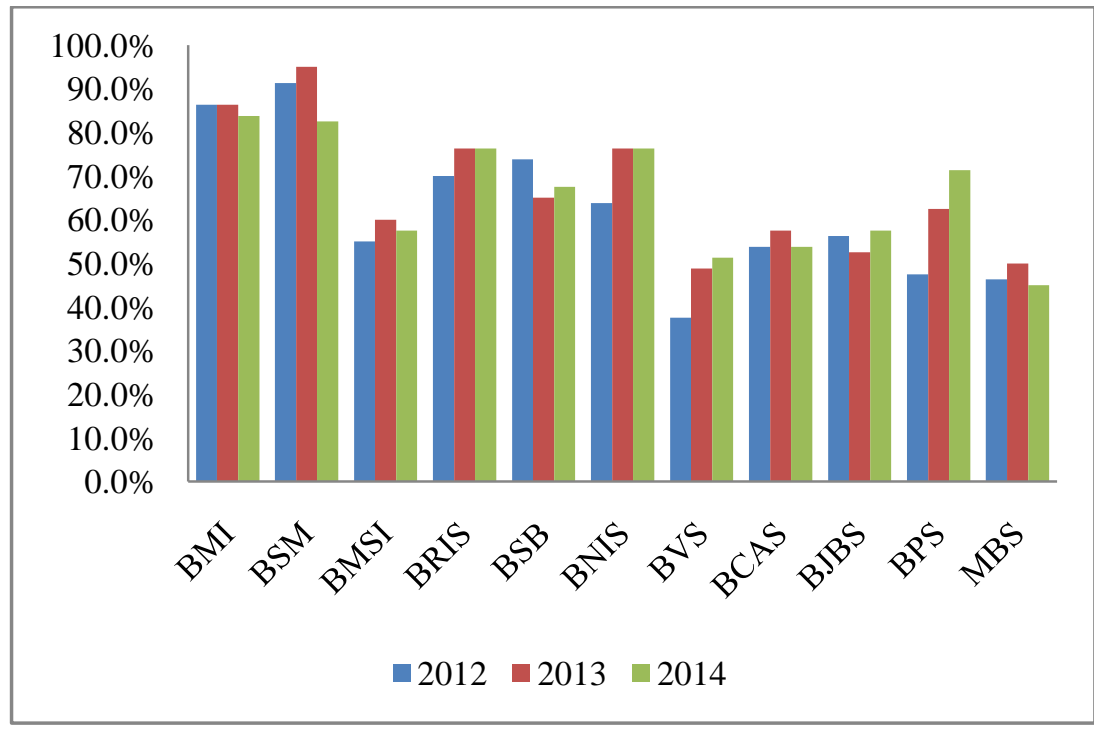

Sumber: Diolah dari data sekunder

Indeks ISR pada tahun 2012, Bank Muamalat mendapatkan skor 86,3\% dengan pengungkapan sebanyak 69 item sehingga predikat yang didapatkan adalah Sangat Informatif. Kemudian di tahun 2013 perolehan skor masih stabil yaitu sebesar $86 \%$ dengan pengungkapan sebanyak 69 item dan predikat yang didapatkan adalah Sangat Informatif. Sedangkan pada tahun 2014 skor ISR menurun menjadi 83,8\% dikarenakan adanya pengurangan pengungkapan pada tema sosial sebanyak 2 item dari tahun sebelumnya yaitu tidak melakukan kegiatan CSR berupa bantuan pendirian/renovasi sekolah dan kegiatan sosial lainnya seperti pemberian buku, pembagian Al-Qur'an dan lain-lain.

Bank Syariah Mandiri Pada tahun 2012 mendapatkan skor 91,3\% dengan pengungkapan sebanyak 73 item, sehingga predikat yang didapatkan adalah Sangat Infomatif. Pada tahun 2013 skor meningkat menjadi 95\% dengan adanya penambahan pengungkapan menjadi 76 item, pada tahun tersebut Bank Syariah Mandiri telah berhasil melakukan kegiatan 
pengembangan generasi muda dengan cara mengembangkan usaha-usaha kecil sehingga dapat meningkatkan kualitas hidup miskin, dan memiliki sistem manajemen lingkungan hidup yang baik. sehingga predikat yang diperoleh adalah Sangat Informatif. Sedangkan, pada tahun 2014 skor ISR menurun drastis menjadi 82,5\% dengan pengungkapan hanya 66 item. Hal ini disebabkan banyaknya kegiatan CSR yang tidak dilakukan seperti: sedekah, wakaf, zakat yang berasal dari karyawan, bantuan dalam bentuk kesehatan, kegiatan penghijauan/go green, kenservasi lingkungan hidup, dan pendidikan lingkungan hidup.

Bank Mega Syariah pada tahun 2012 memperoleh skor ISR 55\% dengan pengungkapan hanya 44 item dan predikat yang didapatkan adalah Tidak Informatif. Kemudian tahun 2013 skor ISR naik menjadi 60\% dengan adanya penambahan pengungkapan menjadi 48 item dikarenakan adanya kegiatan yang bermanfaat buat generasi muda seperti melakukan pengembangan usaha dll, namun predikat yang didapatkan Kurang Informatif. Sedangkan, pada tahun 2014 terjadi penurunan skor ISR menjadi $57,5 \%$ disebabkan adanya pengurangan 1 (satu) item di tema Pendanaan dan Investasi dan 1 (satu) item di tema Tenaga Kerja sehingga predikat yang didapatkan masih Kurang Informatif.

Bank Rakyat Indonesia pada tahun 2012 memperoleh skor 70\% dengan adanya pengungkapan sebanyak 56 item, dan predikat yang didapatkan adalah Informatif. Tahun 2013 skor meningkat menjadi 76,3\% dengan adanya penambahan pengungkapan menjadi 61 item yang mana pada tahun tersebut telah melakukan penanganan keluhan nasabah dan memperhatikan kesehatan serta keselamatan karyawannya sehingga predikat yang didapatkan Informatif. Sedangkan, pada tahun 2014 skor berada pada titik stabil yaitu 76,3\% dengan perolehan nilai pengungkapan 46 item dan predikat yang didapatkan adalah Informatif.

Bank Syariah Bukopin pada tahun 2012 memperoleh skor 73,8\% dengan perolehan nilai pengungkapan sebanyak 59 item sehingga predikat yang diterima adalah Informatif. Pada tahun 2013 item yang diungkapkan hanya 52 dengan skor $65 \%$. Hal ini disebabkan pada tahun tersebut Bank Syariah Bukopin tidak menyalurkan dana sedekahnya untuk kegitan sosial, dan bantuan pendirian sekolah sehingga predikatnya. Kemudian pada tema Pendanaan dan Investasi terjadi pengurangan 1 (satu) item, tema Tenaga Kerja 4 (empat) item, tema Sosial 2 (dua) item. Sehingga mendapatkan predikat Kurang Informatif. Pada tahun 2014 skor meningkat menjadi 67,5\% dengan adanya pengungkapan menjadi 54 item namun predikat yang didapatkan masih sama yaitu Kurang Informatif.

Bank Negara Indonesia pada tahun 2012 memperoleh skor 63,8\% dengan pengungkapan sebanyak 51 item dan predikat yang diperoleh masih Kurang informatif. Namun pada tahun 2013 terjadi peningkatan skor menjadi $76,3 \%$ dengan adanya penambahan pengungkapan menjadi 61 item yang pada tahun tersebut terjadi beberapa kegiatan seperti: melakukan penanganan keluhan nasabah, melakukan kegiatan ibadah pengajian rutin, kampanye go green, pengelolaan air bersih dll. Sehingga predikat yang didapatkan menjadi 
Informatif. Pada tahun 2014 skor yang diperoleh stabil yaitu mencapai 76,3\% dengan predikat Informatif.

Bank Victoria Syariah pada tahun 2012 memperoleh skor 37,5\% dengan penngungkapan sebanyak 30 item, sehingga predikat yang didapatkan pada tahun tersebut adalah Tidak Informatif. Kemudian pada tahun 2013 meningkat menjadi $48,8 \%$ dengan penambahan pengungkapan menjadi 39 item namun predikat yang didapatkan masih sama dengan tahun sebelumnya yaitu Tidak Informatif. Pada tahun 2014 skor kembali meningkat menjadi $51,3 \%$ dengan adanya penambahan pengungkapan menjadi 41 item yang mana pada tahun tersebut terdapat penyelesaian atas perkara hokum dan adanya pengungkapan etika perusahaan / bisnis. Namun walaupun adanya peningkatan skor, predikat yang didapatkan masih berada pada posisi Kurang Informatif.

Bank Central Asia Syariah pada tahun 2012 memperoleh skor 53,8\% dengan pengungkapan sebanyak 43 item dan predikat yang didapatkan adalah Kurang Informatif. Pada tahun 2013 terjadi peningkatan skor menjadi 57,5\% disebabkan adanya penambahan pengungkapan menjadi 46 item, yang mana pada tahun tersebut Bank Centra Asia Syariah telah melakukan beberapa kegiatan sosial diantaranya: pemberian bantuan beasiswa sekolah, pemberdayaan ekonomi, meningkatkan kualitas hidup masyarakat miskin, bantuan kesehatan dan kegiatan sosial lainnya. Namun, predikat yang didapatkan masih Kurang Informatif. Sedangkan pada tahun 2014 terjadi penurunan skor menjadi 53,8\%, skor tersebut sama dengan tahun 2012 yaitu dengan adanya pengungkapan sebanyak 43 item. Sehingga predikat yang didapatkan adalah Kurang Informatif.

Bank Jabar Banten Syariah pada tahun 2012 memperoleh skor 56,3\% dengan pengungkapan sebanyak 45 item, sehingga predikat yang didapatkan pada tahun tersebut addalah Kurang Informatif. Pada tahun 2013 terjadi penurunan skor menjadi 52,5\% disebabkan adanya pengurangan pengungkapan menjadi 42 item dan predikat yang didapatkan Kurang Informatif. Namun skor pada tahun 2014 terjadi peningkatan kembali menjadi 57,5\% dengan pengungkapan sebanyak 46 item, yang mana penambahan item tersebut hanya beda 1 (satu) item dengan tahun 2012 yaitu terdapat kegiatan mengurangi pemanasan global seperti pengelolaan air bersih. Namun, predikat yang didapatkan masih sama yaitu Kurang Informatif.

Bank Panin Syariah pada tahun 2012 memperoleh skor 47,5\% dengan pengungkapan sebanyak 38 item, dan predikat yang didapatkan adalah Tidak Informatif. Kemudian pada tahun 2013 terjadi peningkatan skor menjadi $62,5 \%$ disebabkan adanya penambahan pengungkapan menjadi 50 item yang mana pada tahun tersebut Bank Panin Syariah telah melakukan pengungkapan atas sumber, jumlah dan penerima zakat dari perusahaan atau diari karyawan, kegiatan dlam penanganan keluhan nasabah dan membangun program jenjang karir karyawan, namun predikat yang didapatkan masih Kurang Informatif. Adapaun peningkatan skor yang signifikan terjadi pada tahun 2014 dengan perolehan skor 71,3 dengan adanya penambahan 
pengungkapan menjadi 57 item, sehingga predikat yang didapatkan menjadi Infomatif.

Maybank Syariah pada tahun 2012 memperoleh skor 46,3\% dengan pengungkapan sebanyak 37 item dan predikat yang didapatkan adalah Tidak Informatif. Pada tahun 2013 terjadi peningkatan skor menjadi 50\% disebabakan adanya penambahan pengungkapan menjadi 40 item, hal ini karena pada tahun tersebut Maybank telah melakukan kegiatan sosial dalam bentuk bantuan pendirian atau renovasi sekolah, dalam bentuk financial dan non financial, pembangunan atau renovasi masjid, bantuan kesehatan dan kegiatan sosial lainnya. Namun peningkatan skor tersebut tidak mengubah predikat yang didapatkan yaitu Tidak Informatif. Sedangkan, pada tahun 2014 skor ISR kembali turun menjadi $45 \%$ dengan pengungkapan sebanyak 36 item. Perolehan skor tersebut lebih kecil jika dibandingkan dengan tahun 2012 dan 2013. Sehingga predikat yang didapatkan adalah Tidak Informatif.

Grafik 3. Tingkat Pengungkapan CSR pada Bank Umum Syariah Berdasarkan Indeks ISR Pada Tahun 2012-2014

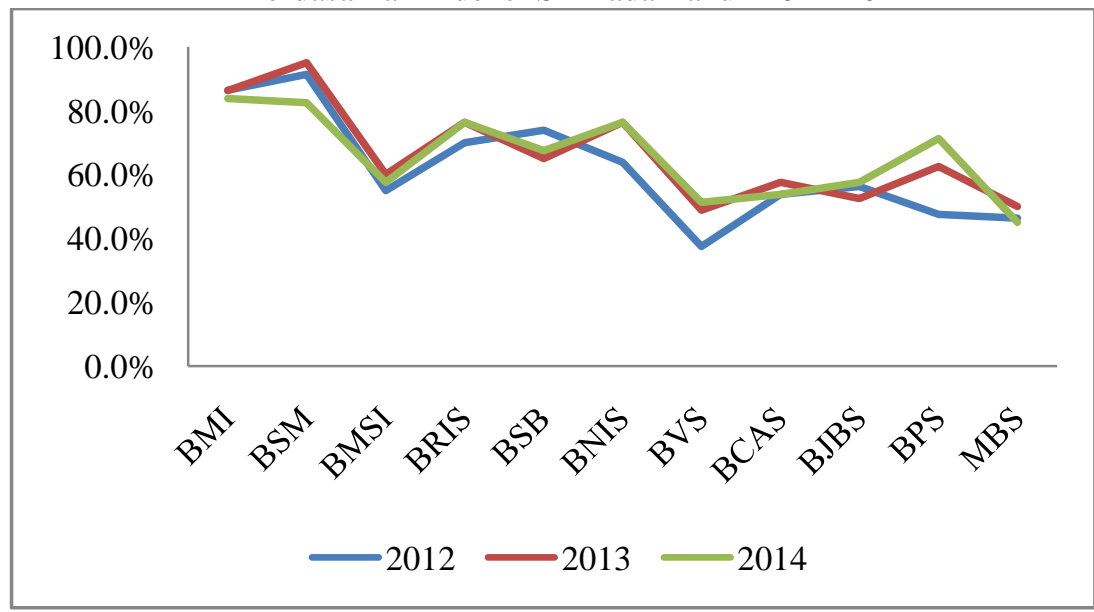

Sumber: Diolah dari data sekunder

Dari grafik 3 diatas dapat disimpulkan bahwa pengungkapan CSR berdasarkan Indeks ISR pada Bank Umum Syariah terus mengalami peningkatan setiap tahunnya. Pada tahun 2012, Bank Umum Syariah yang dianggap telah baik dalam pengungkapan CSR berdasarkan Indeks ISR sebanyak 4 (empat) Bank Syariah. Sedangkan, pada tahun 2013 mendapatkan hasil yang sama dengan tahun sebelumnya yaitu terdapat 4 (empat) Bank Syariah yang dianggap sudah baik pengungkapan CSR berdasarkan Indeks ISR. Kemudian pada tahun 2014, terjadi peningkatan yang signifikan yaitu terdapat 6 (enam) Bank Syariah yang dianggap sudah baik dalam pengungkapan CSR berdasarkan Indeks ISR.

Hasil penelitian ini sekaligus memberikan konfirmasi terhadap penelitian Fitria dan Hartati (2010) bahwa dengan menggunakan Indikator ISR yang lebih komprehensif ternyata hasil yang diperoleh menjadi lebih 
baik, kemudian mengkonfirmasi pula hasi temuan Gustani dan Bayinah (2014) bahwa pada tahun 2014 telah terdapat 6 Bank Syariah yang mendapatkan predikat Informatif dan Sangat Informatif.

Berdasarkan hasil pengungkapan Indeks ISR pada Bank Umum Syariah di Indonesia yang mana pada tahun 2014 terdapat 6 (enam) BUS yang dianggap sudah baik dalam hal pengungkapan ISR. Oleh karena itu, sudah seharusnya Bank Umum Syariah di Indonesia dalam melaporkan CSR nya dengan menggunakan alat ukur Indeks ISR sehingga pelaporan CSR berdasarkan Indeks ISR bukan lagi menjadi suatu hal yang suka rela namun menjadi hal yang wajib bagi entitas syariah.

Adapun dampak yang diperoleh Bank Umum Syariah ketika menggunakan Indeks ISR sebagai alat ukur dalam pelaporan CSR nya adalah sebagai berikut:

1. Dapat menunjukan kepada masyarakat mengenai peran perusahaan dalam perspektif spiritualnya (Haniffa R. , 2002). Sehingga masyarakat tidak hanya mengetahui tentang peran perusahaan terhadap perekonomian saja, melainkan lebih luas dari pada itu dengan mengetahui kegiatan sosial, lingkungan, karyawan dan lain sebagainya dengan berlandaskan nilai-nilai islami didalamnya.

2. Dapat memberikan feedback yang baik bagi Bank Umum Syariah seperti dalam hal peningkatan penjualan produk, karena pada dasarnya Indeks ISR sangat memperhatikan kehalalan atas produk yang dihasilkan. Kemudian dampak positif yang diperoleh perusahaan ketika menerapkan alat ukur ISR adalah karyawan akan lebih sejahtera sehingga mendapatkan perlindungan yang lebih karena Indeks ISR sangat memperhatikan sikap dan perilaku terhadap karyawan lebih luas seperti tersedianya tempat ibadah yang memadai.

3. Akan mempererat hubungan antara perusahaan dengan para stakeholder nya. Hal ini dikarenakan stakeholder merasa yakin dan percaya atas dana yang diinvestasikannya akan aman. Indeks ISR pun telah memperhatikan aktivitas yang mengandung riba, gharar, dan maysir. Sehingga perusahaan dapat terhindar dari aktivitas yang terlarang.

\section{KESIMPULAN}

Berdasarkan hasil skor yang diperoleh tersebut dapat ditentukan tingkat konsistensi perolehan predikat Bank Umum Syariah pada tahun 2012 sampai 2014 yang mana Bank Muamalat dan Bank Syariah Mandiri konsisten meraih predikat Sangat Informatif pada tahun 2012 sampai 2014. Bank Rakyat Indonesia Syariah pun setiap tahunnya selalu konsisten memperoleh predikat Informatif. Bank Syariah Bukopin mendapatkan predikat Kurang Informatif hanya pada tahun 2013 namun pada tahun 2012 dan 2014 predikat yang didapatkan adalah Informatif. 
Berbeda halnya dengan Bank Negara Indonesia Syariah yang mendapatkan predikat Tidak Informatif pada tahun 2012 namun pada tahun 2013 dan 2014 meningkat secara signifikan menjadi Informatif. Bank Panin Syariah mengalami peningkatan dari tahun ke tahun secara bertahap dimana pada tahun 2012 hanya mendapatkan predikat Tidak Informatif, tahun 2013 menjadi Kurang Informatif, dan tahun 2014 menjadi Informatif. Bank Mega Syariah, Bank Centra Asia Syariah dan Bank Jabar Banten Syariah pada tahun 2012 sampai 2014 sealu mendapatkan predikat Kurang Informatif. Sedangkan Bank Victoria Syariah pada tahun 2012 dan 2013 mendapatkan predikat Tidak Informatif namun pada tahun 2014 mendapatkan predikat Kurang Informatif. Adapun Bank syariah yang selalu mendapatkan predikat Tidak Informatif dari tahun 2012 sampai 2014 adalah Maybank Syariah

\section{DAFTAR PUSTAKA}

Antonio, M. S. (2001). Bank Syariah dari Teori ke paraktik. Jakarta: Gema insani press.

Azizah, A. I., \& A. Birton, M. N. (2015). Tingkat Pengungkapan Corporate Social Responsibility Bank Syariah di Indonesia. Jurnal SEBI .

Bungin, B. (2006). Metodologi Penelitian Kualitatif Aktualisasi Metodologis ke arah Ragam Varian Kontemporer. Jakarta: Rajawali Pers.

Cahyati, A. D. (2008). Corporate Social Responsibility : Perspektif Akuntansi. Jurnal LPPM : Paradigma , 9 No. 01.

Fauziah, K., \& Yudho, P. (2013). Analisis Pengungkapan Tanggung Jawab Sosial Perbankan Syariah Di Indonesia Berdasarkan Islamic Social Reporting Indeks. Jurnal Dinamika Akuntansi , 5 No. 1.

Fitria, S., \& Hartanti, D. (2010). Islam dan Tanggung Jawab Social: Studi Perbandingan Pengungkapan Berdasarkan Global Reporting Initiative Indeks dan Islamic Social Reporting Indeks. SNA XIII .

Gustani, \& Bayinah, A. n. (2014). Model pelaporan kinerja sosial perbankan syariah : implementasi islamic social reporting index (Index ISR) di indonesia. Jurnal Akuntansi dan keuangan Islam , 2 No. 1.

Haniffa, R. (2002). Social Reporting Disclosure: An Islamic Perspective. Indonesia Management \& Accounting Research.

Othman, R., \& Thani, A. M. (2010). Islamic Social Reporting Of Listed Companies In Malaysia. International Business \& Economics Research Journal ,3, 135-144. 9 Number 4.

Othman, R., Thani, A. M., \& Ghani, E. K. (2009, October). Determinants of Islamic Social Reporting Among Top Shariah-Approved Companiest in Bursa Malaysia. Research Journal Of International Studies -Issue 12 . 
Putra, H. F. (2014). Corporate Social Reporting pada perbankan syariah di Indonesia berdasarkan indeks Islamic social reporting (ISR).

Sofyani, H., \& Setiawan, A. (2012). Perbankan Syariah Dan Tanggungjawab Sosial: Sebuah Studi Komparasi Indonesia Dan Malaysia Dengan Pendekatan Islamic Social Reporting Index Dan Globalreporting Initiative Index. Prosiding.

Sofyani, H., Ulum, I., Syam, D., \& Wahjuni L, S. (2012, Maret). Sofyani, H., Ulum, I., Syam, D., \& Wahyuni, S. (2012, Maret). Islamic Social Reporting Sebagai Model Pengukuran Kinerja Sosial Perbankan Syariah (Studi Komparasi Indonesia dan Melayu). JDA, Vol. 4 No. 1, hal. 36-46.

Suhendi, C., \& Indriastuti, M. (2014). CSR Disclosure Evidence In Indonesia: Sharia And Non Sharia Bank. South East Asia Journal of Contemporary Business, Economics and Law, , Vol. 4, Issue 2 (June).

Ullah, M. H., \& Rahman, M. A. (2013). Corporate social responsibility reporting practices in banking companies in Bangladesh Impact of regulatory change. Journal of Financial Reporting and Accounting , 13 (2 pp. $200-2252$ ). 
